\title{
Risk Factors in the Hygienic Quality of Milk in Ghana
}

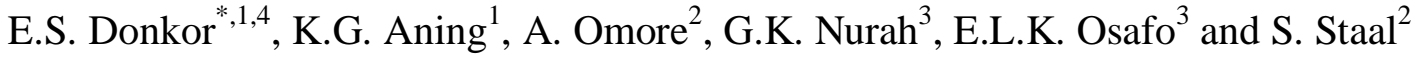 \\ ${ }^{1}$ Animal Research Institute, Council for Scientific and Industrial Research, Achimota, Ghana \\ ${ }^{2}$ International Livestock Research Institute, Nairobi, Kenya \\ ${ }^{3}$ Faculty of Agriculture, Kwame Nkrumah University of Science and Technology, Kumasi, Ghana \\ ${ }^{4}$ Department of Microbiology, University of Ghana Medical School, College of Health Sciences, Accra, Ghana
}

\begin{abstract}
The study was carried out to identify risk factors associated with bacterial contamination of locally produced raw milk and its adulteration with water. A total of 419 respondents of different categories of milk agents in the study sites were sampled for data and milk collection in the dry and wet seasons. The data collected focused on milk marketing factors and handling practices likely to affect milk quality, while the milk samples were analysed to determine the extent of bacterial contamination and adulteration with water. The proportion of milk samples adulterated was $18 \%$. While $23.5 \%$ of the milk samples had unacceptably high total plate count $\left(>6.3 \log _{10} \mathrm{cfu} / \mathrm{ml}\right)$, all the samples had unacceptably high coliform plate count $\left(>0.7 \log _{10} \mathrm{cfu} / \mathrm{ml}\right)$. Risk factors associated with high bacterial counts were related to milk marketing channels $(\mathrm{p}<0.05)$, milk market agents $(\mathrm{p}<0.01)$, and milk containers $(\mathrm{p}=0.06)$ as well as their mode of cleaning $(\mathrm{p}=0.06)$. The only risk factor identified for adulteration of milk was related to season $(\mathrm{p}=0.04)$.
\end{abstract}

\section{INTRODUCTION}

While milk is highly nutritious, its quality is easily tarnished and rendered unsafe for consumption by foreign agents. The hygienic quality of milk is measured by the extent of milk contamination and may be determined by the bacterial population present in milk. A high bacterial count is an indication of poor hygiene, reduces shelf life of the milk, and enhances the risk of milk-borne bacterial infections $[1,2]$. Poor hygiene often arises from poor handling, and common sources of bacterial contamination, include faeces, personnel, and containers. Additionally, the hygienic quality of milk may be affected seriously by adulteration with contaminated water. Such interferences also reduce the compositional, nutritional, and processing quality of milk.

Informal milk markets have been shown to account for over $80 \%$ of milk sales in most sub-Saharan African countries, and earlier studies have shown that consumers enjoy convenient delivery and lower prices from such informal markets [3]. However, such markets are being discouraged for public health reasons.

In Ghana, dairying is a young and developing industry. A major problem it faces is low demand for the milk produced, mainly because of concerns over the hygienic quality and safety of the milk. The practice of pasteurisation in the country is not encouraging as studies have shown that less than $10 \%$ of milk market agents pasteurise milk [4]. Health risks related to hygienic quality of milk in the country have been documented [5-7]. However, the predisposing factors remain unknown. This ultimately affects formulation of appropriate recommendations and measures needed to improve the quality and safety of the milk. The study was aimed at assessing the hygienic quality of milk and determining the risk factors

*Address correspondence to this author at the Department of Microbiology, University of Ghana Medical School, College of Health Sciences, Accra, Ghana; E-mail: ericsdon@ hotmail.com associated with poor hygienic quality. The findings would help in the formulation of appropriate recommendations to improve the hygienic quality of informally marketed milk in Ghana, which could go along way to stimulate growth of the dairy industry.

\section{MATERIALS AND METHODS}

\section{Study Area and Sampling}

The study was carried out at two sites namely, the periurban areas of Accra and Kumasi, the two cities in Ghana (Fig. 1). The areas were selected to represent a variation in consumer concentration, market access, and dairy production intensity. Accra that has a higher population density was chosen to represent high market access and relatively more intensive dairy production compared to Kumasi that has a lower population density, medium market access and more extensive dairy production systems around it.

The study was carried out in two steps. First, Participatory Rural Appraisals (PRAs) were conducted among consumers, marketing agents and producer-sellers at each study site at the beginning of the research to identify consumer preferences and practices, types of marketed dairy products, major marketing pathways, points and milk handling practices by market agents.

In the second step, the information obtained during the PRAs was used to construct a structured questionnaire and to select locations for field surveys in specific areas considered by key informants to have dairy marketing as an important activity. In and around both cities, data were collected in these locations by questionnaire from randomly selected milk traders during the dry (December 1999 - March 2000 and in Kumasi area and March - June 2000 in Accra area) and wet (July - September 2000 in Kumasi area and July October 2000 in Accra area) seasons. Respondents comprised different categories of market agents including producers (some of whom were herdsmen who own the milk but not the animals), processors, wholesalers or assemblers, and 


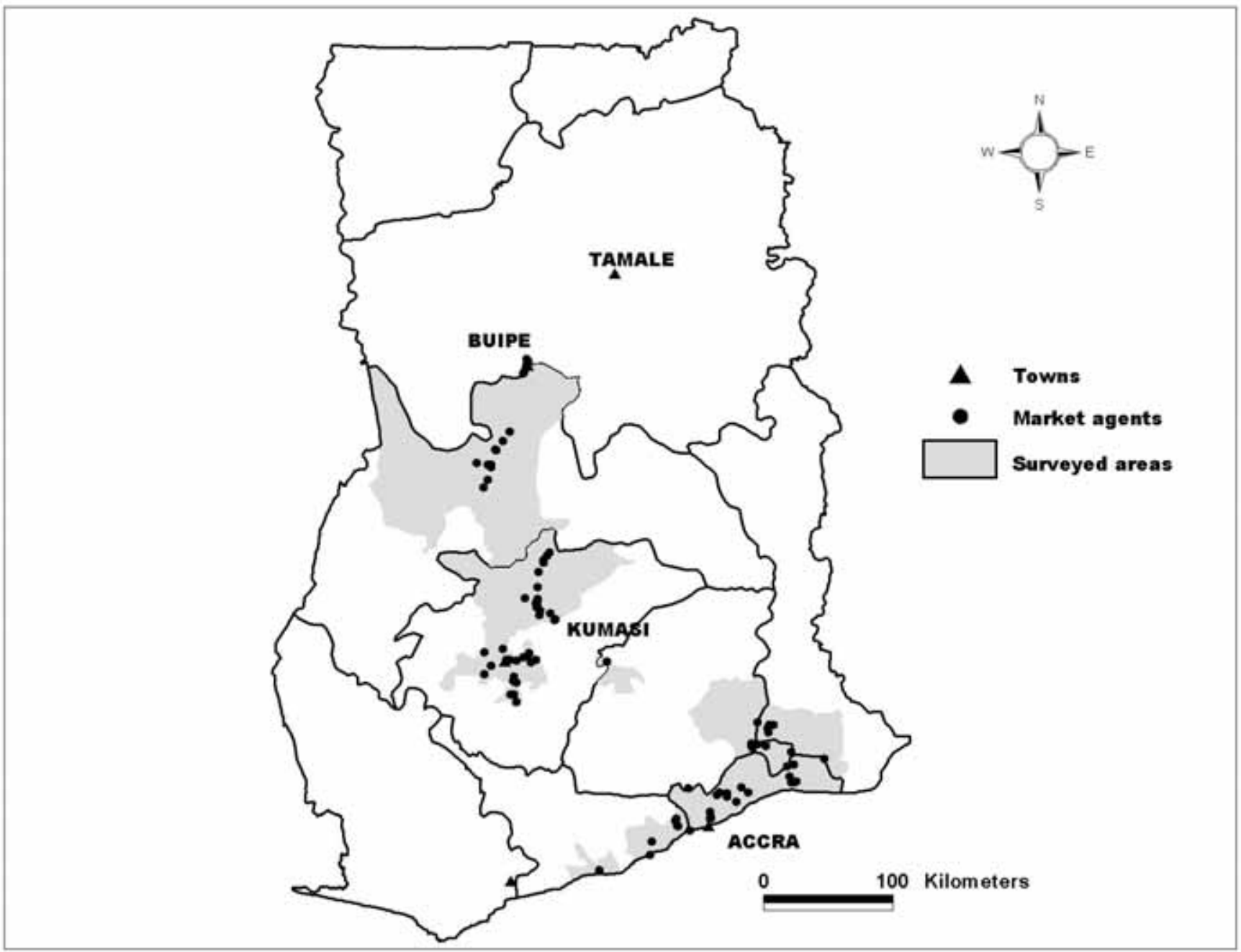

Fig. (1). Map of study sites in Ghana.

retailers. The data collected from the market agents focused on milk handling practices, milk procurement, milk sale, and hygiene of premises and personnel. Milk samples were also collected from the market agents, and more than one sample was collected per respondent in 11 cases where product differences or handling warranted it.

The sampling of market agents varied by their location and type (Table 1). A total of 5 locations were sampled in Accra. In Kumasi area, market agents were sampled in 7 locations, including Buipe $(294 \mathrm{~km}$ north of Kumasi) that is also a source of milk for Kumasi market. All bulking centres (wholesalers or assemblers) were sampled. Smaller scale market agents (producer-sellers, processors and retailers) were identified through local informants and up to 30 of them sampled randomly at each selected location. Simultaneously with the structured interviews, samples of milk and dairy products were collected from each market agent interviewed. The milk samples were collected into sterile containers and transported on ice to the laboratory for analysis.

\section{Laboratory Analyses}

Milk samples were assessed for Total Plate Count (TPC) and Coliform Plate Count (CPC) using direct culture methods described by Speck [8] and Marshall [9]. Counts higher than $6.3 \log _{10} \mathrm{cfu} / \mathrm{ml}$ and $0.7 \log _{10} \mathrm{cfu} / \mathrm{ml}$ for TPC and CPC respectively were considered unacceptably high according to the standards of the Ghana Standards Board. The butterfat content and specific gravity of the samples were also determined and used to calculate the Solids-Not-Fat (SNF) content of the milk by the Richmond's formulae as follows: \% $\mathrm{SNF}=(0.2 \times \%$ fat $)+\left(0.25 \times{ }^{0} \mathrm{~L}\right)+0.48$. Milk samples with $\mathrm{SNF}<8.5$ were considered to be adulterated while those with $\mathrm{SNF}>8.5$ were considered unadulterated [10].

\section{Data Analyses}

The laboratory analyses results and data collected from market agents were entered in MS-ACCESS and MSEXCEL and analysed in STATA 6.0 to identify risk factors associated with high bacterial counts and adulteration of milk. The approaches taken to analyse the data were as follows: Firstly, descriptive analyses were carried out and variables were described by frequencies, geometric means, ranges, standard deviations, and proportions above given standards. Following the descriptive analyses, regression analyses were conducted using the milk quality indicators (SNF, TPC, and CPC) as response variables, and milk handling factors likely to affect the quality indicators as explanatory variables. For each milk quality indicator, tests of significance ( $\mathrm{p}$-values) were used to identify significant as- 
sociations $(p<0.10)$ with the explanatory variables. The specific explanatory variables significantly associated with high TPC and CPC were identified as risk factors for TPC and $\mathrm{CPC}$ respectively. Similarly the specific explanatory variables significantly associated with low SNF were identified as risk factors for adulteration.

Table 1. Market Agents Surveyed and Sampled in Each Site and Season

\begin{tabular}{|l|c|c|}
\hline \multicolumn{1}{|c|}{ Season } & Dry & Wet \\
\hline Sample Category \& Location & Number (N) & Number (N) \\
\hline \hline Market Agents in Accra & & \\
\hline Producer-sellers & 44 & 47 \\
\hline Processor & 3 & 2 \\
\hline Wholesaler (assemblers) & 25 & 19 \\
\hline Retailer & 12 & 4 \\
\hline Overall & 84 & 72 \\
\hline Date & $\mathbf{1 2 / 9 9 - 3 / 0 0}$ & $\mathbf{7 - 9 / 0 0}$ \\
\hline \hline Market Agents in Kumasi & & \\
\hline Producer-sellers & 76 & 60 \\
\hline Processor & 8 & 11 \\
\hline Wholesaler (assemblers) & 5 & 5 \\
\hline Retailer & 55 & 18 \\
\hline Overall & 144 & 94 \\
\hline Overall (all mkt agents) & 228 & 166 \\
\hline
\end{tabular}

\section{RESULTS}

The geometric means of TPC, CPC, and SNF were 5.9 $\log _{10} \mathrm{cfu} / \mathrm{ml}, 3.7 \log _{10} \mathrm{cfu} / \mathrm{ml}$ and $8.8 \%$ respectively. The proportion of milk samples adulterated with water as determined by SNF values was $18 \%$. While $23.5 \%$ of the milk samples had unacceptably high TPC, all the samples had unacceptably high CPC.

The various risk factors associated with high TPC and $\mathrm{CPC}$ as well as adulteration, are reported in Table 2. The risk factors were related to milk marketing channels, milk mar- keting agents, and milk containers as well as their mode of cleaning. High TPC was specifically associated with the use of gravels $(\mathrm{p}=0.04)$ compared with sponge for cleaning milk containers. High CPC was specifically associated with milk of assemblers $(\mathrm{p}<0.01)$, and two milk channels, namely, Herdsman_Processor (milk sourced from herdsmen to processors) $(\mathrm{p}=0.03)$ and Trader/hawker_Retailer (milk sourced from Trader/hawker to other retailers) $(\mathrm{p}=0.04)$. Plastic containers $(p=0.06)$, and the use of soap $(p=0.06)$ instead of detergents for cleaning milk containers, were also associated with high CPC. Adulteration of milk with water was associated with the wet season $(\mathrm{p}=0.04)$.

\section{DISCUSSION}

The hygienic quality of milk has serious implications on its economic value and more importantly on its public health safety. TPC reflect time elapsed since milking and the ambient temperature (if milk is not chilled), while CPC are especially associated with level of hygiene since coliform bacteria are mainly of faecal origin. While a minority of the samples had unacceptable TPC, all of them had unacceptable $\mathrm{CPC}$. These findings essentially reflect poor hygienic handling of raw milk in the country and similar findings have been reported by other workers [5,7].

It was observed during the study that milking of the cow was usually done in the kraals, which often were contaminated with mud, cow dung and urine. Many flies usually surrounded the milk containers during milking and it was common to find particles of dirt, cow dung and some flies in the milk during and after collection. Overall, adulteration of milk with water was $18 \%$ which is quite high compared with rates observed in other countries such as Kenya [11]. The water used by most traders was untreated water such as streams and rivers, and the practice of adding such water to milk may have contributed to its poor bacteriological quality.

Five main risk factors associated with high $\mathrm{CPC}$, high TPC, and adulteration were identified. High CPC or poor hygiene was associated specifically with two milk marketing channels, namely, Herdsman_Processor and Trader/hawker_ Retailer. The problem of poor hygienic handling of milk in Ghana has been recognised by several workers [6,7]. However, the work of these researchers indicated the problem at only the farm level. The association of Trader/hawker_Retailer milk channel with poor hygiene in this study indicates that milk contamination from poor hygiene is not limited to only the milking environment at the farm, but includes the hygienic practices of milk traders outside the farm. This is

Table 2. Risk Factors Associated with Bacterial Contamination and Adulteration of Raw Milk Samples

\begin{tabular}{|c|c|c|c|c|}
\hline Milk Quality Indicator & Risk Factor & $p$-Value & SE & Est. \\
\hline Adulteration & Wet season & 0.04 & 0.15 & 0.32 \\
\hline \multirow{5}{*}{ High CPC } & Plastic container & 0.06 & 0.31 & 0.59 \\
\hline & Cleaning of milk containers with soap & 0.06 & 0.46 & 0.89 \\
\hline & Milk sold by milk assemblers & 0.00 & 1.02 & 3.59 \\
\hline & Milk pathway from Herdsman to Processor & 0.03 & 1.69 & 3.67 \\
\hline & Milk pathway from Trader (hawker) to Retailer & 0.04 & 2.7 & 5.53 \\
\hline High TPC & Cleaning of milk containers with gravels & 0.04 & 0.41 & 0.85 \\
\hline
\end{tabular}


side the farm. This is confirmed by the high CPC associated with the milk of wholesalers.

Another risk factor of high CPC was the type of milk container used. Plastic containers, which was the type used by almost all market agents was associated with high CPC compared with other container types which included mainly metal and wood. Apart from most of such plastic containers not being of food grade quality, the design and construction of some constrains cleaning because of restricted access to the container bottom. Coliform bacteria can rapidly build up in moist milky residues in such containers, which then become major sources of contamination of milk [12]. The association of high CPC and high TPC with cleaning of milk containers by gravels (compared with sponge) and soap (compared with detergents) respectively, indicate that these agents are relatively less effective for cleaning.

Season was the only risk factor associated with adulteration of milk, with the wet season showing higher levels of adulteration. The relationship of high adulteration with the wet season rather than the dry season conflicts with the normal tendency to add water to milk during periods of low milk supply in the dry season. This indicates that, in Ghana, adulteration of milk with water may not be primarily related to amount of milk supply. Further studies are required to establish the main factors underlying the practice of adulterating milk with water in the country.

The five risk factors discussed above may serve as important critical control points for improving the hygienic quality and safety of raw milk in the country. It is submitted that if the recommendations of this study are implemented, it would not only protect public health, but also attract high patronage and stimulate growth of the Ghanaian dairy industry.

\section{ACKNOWLEDGEMENTS}

The paper is an output of a research and development project funded by UK department for International Development (DFID) for the benefit of developing countries. The technical support provided by F. K. Kwarteng, P.W.K. Nartey, S. Ogbete and C. Arthur are gratefully acknowledged.

\section{REFERENCES}

[1] Andrew MHE, Rusell AD Ed. The revival of injured microbes. London: Academic Press, Society for Applied Bacteriology Symposium Series No. 12; 1984

[2] Kayihura M, Kaburia HFA, Arimi SM, Lindquist KJ. Staphylocococcal enterotoxin A in raw and pasteurised milk. East African Med J 1987; 64: 177-181.

[3] Omore AO, McDermott JJ, Staal S, Arimi SM, Kangethe EK. Analysis of public health risks from consumption of informally marketed milk in sub-Saharan African countries. In: Proceedings of the $9^{\text {th }}$ International Symposium on Veterinary Epidemiology and Economics (ISVEE); 2000 August 6-11; Colorado, USA; 2000.

[4] Sampane-Donkor E. A study of milk quality and public health hazards in the smallholder peri-urban dairy marketing system in Ghana. Ghana: Department of Animal Science University of Ghana; 2002.

[5] Abraham CA, Laryea AM. Preliminary investigation of the bacteriology of raw milk produced on the Accra plains. Ghana Med J 1968; 7: 100-103.

[6] Ayebo D, Assoku RKG, Oppong ENW. A study of the bacteriology of raw milk produced on the Accra Plains of Ghana. Ghana J Sci 1976; 16: 9-18.

[7] Karikari PK, Mathias J, Opare E, Okantah SA, Pobee M. Preliminary assessment of the composition and hygienic quality of milk produced in small scale farming systems. Ghana: Animal Research Institute; 1998.

[8] Speck ML. Compendium of methods for the microbiological examination of foods. $2^{\text {nd }}$ ed. Washington DC: American Public Health Association; 1984.

[9] Marshall RT. Standard methods for the examination of dairy products. 16th Ed. Washington DC: American Public Health Association; 1992.

[10] O'Connor CB. Rural dairy technology. Addis Ababa: International Livestock Research Institute; 1994.

[11] Omore A, Arimi S, Kangethe E, et al. Assessing and managing milk-borne health risks for the benefit of consumers in Kenya. Kenya: International Livestock Research Institute; 2001.

[12] Ombui JN, Arimi SM, McDermott JJ, Mbusua SK, Githua A, Muthoni J. Quality of raw milk collected and marketed by diary cooperative societies in Kiambu district, Kenya. Bull Anim Hlth Prod Afri 1995; 43: 277-284. 